\title{
The Environmental Impact of Singles' Consumer Behaviour: Is the Lifestyle of Singles Inevitably Environmentally More Damaging?'
}

\author{
Lukáš Kala
}

\begin{abstract}
Population research in Western countries shows a rising number of singles living in oneperson households. The increase in one-person households is likely to accelerate consumption, deplete resources and degrade nature. Current studies show that solo-living consumes more land, energy, goods and materials per person than living in shared housing. However, even though these rapid demographical changes are having a serious effect on the environment, researchers have not examined the environmental aspects of singlehood in much detail. The purpose of the current study is to minutely determine the environmental and non-environmental aspects of single people's lifestyles. A combination of quantitative and qualitative approaches was used in the analysis of data gathered mostly via in-depth interviews and questionnaires regarding consumption. One of the most significant findings to emerge from this study is that environmentally-friendly changes of lifestyle can reduce the overall environmental impact of solo living.
\end{abstract}

KEYWORDS Singles, solo-living, consumption, lifestyle, consumer behaviour, ecological footprint

\section{Introduction}

After 1989, the demographic trend in the Czech Republic began to copy Western countries, where there was a fundamental transformation of intimate relationships and reproductive behaviour of people in connection with the so-called Second Demographic Transition (van de Kaa 1987). Young people are postponing marriage and starting families at an older age, opting instead to concentrate on individualized values and goals. Marriage is often replaced by various forms of alternative relationships. The proportion of unmarried people in the population is increasing. A significant portion of them live in separate households. Especially in rich post-industrial countries, we see not only an increase of single people in society, but also an increase in single-person households (Hooper et al. 1998).

Especially in housing it is clear that the population in Western countries is changing its way of life from various forms of shared living to greater autonomy and independence. Although living alone is nothing new, an essential difference lies in the fact that it now relates

Sociálni studia. Department of Sociology FSS MU, 3/2015. S. 53-69. ISSN 1214-813X.

1 Financial support for this study was provided by a grant from the Czech Science Foundation "The Meaning of Home for Solo Living People" (13-32237S) and within specific research projects on Faculty of Social Sciences, Masaryk University (MUNI/A/0914/2013, MUNI/A/0769/2013). 
to a large part of the population. The amount of one-person households worldwide in 2006 exceeded 200 million, which, compared to the previous decade, represents an increase of about 50 million (Hodgson 2007). As a result of demographic changes and changes in normative behaviour in Western societies, a dramatic increase in single-person households is expected within the next decade. As this is already growing at $1.6 \%$ per annum, it is estimated that in 2020 there will be 253.8 million of them worldwide (ibid).

A similar development was also recorded in the Czech Republic, where currently 2.7 million people (30\% of those older than 15 years) are single according to marital status (CSO 2011). At the same time, 1.4 million people ( $16 \%$ of those older than 15 years) live in singlemember households (ibid). Single-member households have seen a very dynamic, long-term growth trend. In recent decades, the number of single person households has seen the largest growth ever, in comparison with other types of households, (according to CSO data - for 15 years from 1995 to 2010 up to $83 \%$ ). What is especially striking is the increase in single person households in the younger age categories. From an environmental perspective, the increase in singles, especially those living in single-member households, is an important phenomenon. Numerous empirical studies point to the considerable environmental impact of living in single-member households. While population growth alone is responsible for $1 / 4$ of the increase in energy consumption, the increase of single-person households is responsible for the remaining $3 / 4$ (MacKellar et al. 1995 in Bradbury 2014 et. al). On the basis of data from 50,000 Danish households, a strong correlation between energy consumption and household size was found. In single-person households almost twice as much energy is consumed by one person than in family households (Gram-Hanssen et al. 2009). At the same time, singles consume many more material goods per capita than family households. The increase in single-person households is problematic especially in younger age categories, which are, in terms of resource consumption, relatively the most voracious (e.g. Klinenberg 2012).

Previous studies have reported that an increase in one-person households is likely to have a detrimental environmental impact. Williams (2005) demonstrated that people living on their own consume more energy and create more waste than individuals sharing a home, which could lead to an environmental crisis in the near future. Recently investigators have examined the impact of changing demography on the environment. Liu et al. (2003) determined the impact of declining household size on biodiversity and natural resources. The research indicated that an increase in small households would lead to an increase in resource consumption and loss of biodiversity globally. Surveys such as the one conducted by Cincotta and Engelman (2000) have shown that there is a link between declining household size and diminishing biodiversity, increasing domestic energy consumption (MacKellar et al. 1995 in Bradbury 2014 et al.; Noorman and Uiterkamp 1998), increasing carbon dioxide emissions (Fawcett et al 2002), increasing household waste and total household consumption (Røpke 1999; Sanne 2002).

Even though these rapid demographical changes are having a serious effect on the environment, researchers have not investigated the environmental aspects of singlehood in much detail. Although some research has been carried out on the environmental aspects of solo living, there have been few empirical investigations into the structure of consumption expenditure and the consumption patterns of single people. There has been little qualitative analysis of their way of life. So far, too little attention has been paid to the environmentally 
favourable aspects of single people's lifestyles ${ }^{2}$. No previous study has investigated the lifestyles of single people who identify themselves as environmentalists (hereinafter green singles). However, that research could bring valuable insights into the lifestyle adaptations of singles in context with environmental values.

The major objective of this study was to investigate the environmental and non-environmental aspects of single people's lifestyles. The aim of this study is to investigate the differences between the environmental impact of green singles' and conventional singles' lifestyles. This research seeks to address the following questions: Can the lifestyle of singles actually be considered to be environmentally unfriendly? Which consumption patterns of single people are the worst from an environmental perspective? Is there any difference between the lifestyle of green and conventional singles? Can we find inspirational environmentallyfriendly aspects in the lifestyle of green singles?

A combination of quantitative and qualitative approaches was used in the data gathering and analysis. The starting point of this text is a wider study where qualitative modes of enquiry were applied in an attempt to illuminate the details of consumer practice of surveyed singles (Kala 2014). The study was conducted in the form of a survey, with data being gathered mostly via in-depth interviews (not part of this text) and questionnaires. Thus, this study provides an exciting opportunity to advance our knowledge of the environmental aspects of single people's lifestyles.

The paper has been organised in the following way: The first part gives a brief overview of previous research and reviews the evidence for the environmental unfavourableness of singlehood and solo living. The second part is concerned with the methodology used for this study. The third section presents the findings of the research, focusing on the ecological and carbon footprint of the lifestyle of surveyed singles. Finally, the conclusion gives a brief summary and critique of the findings and includes a discussion of the implications of the findings for future research into this area.

\section{References to previous research}

Much of the current literature on the environmental aspects of single people's lifestyles is primarily concerned with the quantitative description of energy and material flow in their households. Surveys such as that conducted by Williams (2003, 2005 and 2007) have shown that solo living represents a risk to sustainability. Previous research supports the assumption that smaller households are less efficient in terms of energy consumption, transportation and occupation of space per person. Data from several sources has identified that a decrease in household size is associated with an increase in energy consumption (Noorman and Uiterkamp 1997; Williams 2005). According to Williams' findings, one-person households consume up to $77 \%$ more electricity and up to $54 \%$ more gas per capita than multi-person

2 The term lifestyle has broader meaning within the article. It refers to contrasting ways of life found among people who live solo and people who live in couples or families. The term conceptualizes alternative ways of living, usually conspicuous through values and modes of consumption (see Marshall 1998). 
households. For example, the average three-person household consumes about 1,500 KWh less electricity annually and 5,000 KWh less gas per capita than a one-person household (cf. Williams 2003: 45).

Singlehood and especially solo living have been identified as major contributing factors for growing consumption. Surveys, such as that conducted by Hooper et al. (1998), have shown that a relationship exists between household size and the amount of consumption per person. "Reduction in household size takes a double toll on the resource user and biodiversity. Firstly, households mean more housing units, thus generally increasing the amount of land and materials needed for housing construction. Secondly, smaller households have a lower efficiency of resource use per capita because goods and services are shared by more people in larger households" Liu et al (2003). Moreover, they produce 1.49 times more waste per capita than two-person households, and three times more than a four-person household (cf. Noorman and Ulterkamp 1998: 39).

Table 1: Comparison of consumption and waste production in different sized households per person per year (in \%)

\begin{tabular}{|l|c|c|c|}
\hline & one-person household & two-person household & four-person household \\
\hline product consumption & 100 & 75 & 62.5 \\
\hline $\begin{array}{l}\text { consumption } \\
\text { of packaging materials }\end{array}$ & 100 & 75 & 58 \\
\hline water consumption & 100 & 100 & 75 \\
\hline $\begin{array}{l}\text { indirect energy } \\
\text { consumption } \\
\text { (production } \\
\text { and services) }\end{array}$ & 100 & 63 & 42 \\
\hline $\begin{array}{l}\text { consumption } \\
\text { of electricity }\end{array}$ & 100 & 68.5 & 45 \\
\hline consumption of gas & 100 & 64.5 & 39 \\
\hline production of waste & 100 & 88.5 & 75.5 \\
\hline
\end{tabular}

Source: Noorman and Uiterkamp (1998: 39)

Single people are an important part of the consumer market and significant contributors to its growth (Röpke 1999; Sanne 2002). Singles invest a large portion of their income to self-development, education and entertainment (Hawk 2011, Klinenberg 2012). Usually, they have a higher income, which implies higher consumption. As singles (particularly single males aged 35-44) tend to have above average disposable income, they consume more resources (Williams 2003: 195).

It has conclusively been shown that solo living is the highest contributor of great consumption of single people (Holmans 1997; Hogson 2007). Hooper et al. (1998) investigated housing preferences amongst singles. In general they reported that singles tend to prefer owner occupation, spacious accommodation (at least 2 bedrooms ${ }^{3}$ ), housing rather than flats, self-contained dwellings, parking and exterior space, and low maintenance accommodation

3 According to an Australian study, singles mostly prefer three-bedroom detached houses (Wulff et al. 2004). 
with basic appliances (Hooper et al. 1998). According to Williams, they acquire their own apartments mostly in order to rent rooms to supplement their income, for home offices, for hobbies and entertaining guests, to allow for household growth without moving and "because more spacious dwellings are perceived as being a better investment" (2003: 89). Singles in the Czech Republic also prefer larger apartments or detached houses. While in 2001 Czech singles living alone inhabited mostly two-room apartments with an average floor space of $47 \mathrm{~m}^{2}$, now they live in three rooms with an average floor space of $68 \mathrm{~m}^{2}$ (Habartová 2014; Škrabal, Morávková 2003: 232). Williams found that one-person households occupy an average of $30.7 \mathrm{~m}^{2}$ floor space more per capita than a two-person household and even $43.9 \mathrm{~m}^{2}$ more than a four-person household (Williams 2003: 46). Therefore, as a number of authors mentioned above have reported, singles prefer similar housing as couples or families, and when they begin to live independently, they are not willing to share their home with others (i.e. Williams 2003).

Some authors point out that the growing number of one-person households has contributed to the increasing demand for energy, goods, services and infrastructure; at the same time they produce more waste and occupy a larger area than in the past (cf. Kušková 2009). Some studies have revealed that one-person households have a considerable ecological impact measurable through their ecological footprint. Within research on the ecological footprint of households, Roy and Caird have noted that there has been a decline in the total ecological footprint per person as households have got larger, and especially as size has grown from single- and two-person to 3-, 4- or more person households (2002: 277-279). This finding reinforces other works that have shown the highly negative effect on the environment, especially concerning energy consumption, personal transport and land for housing, of the shift to eversmaller households.

Figure 1: The average ecological footprint of households

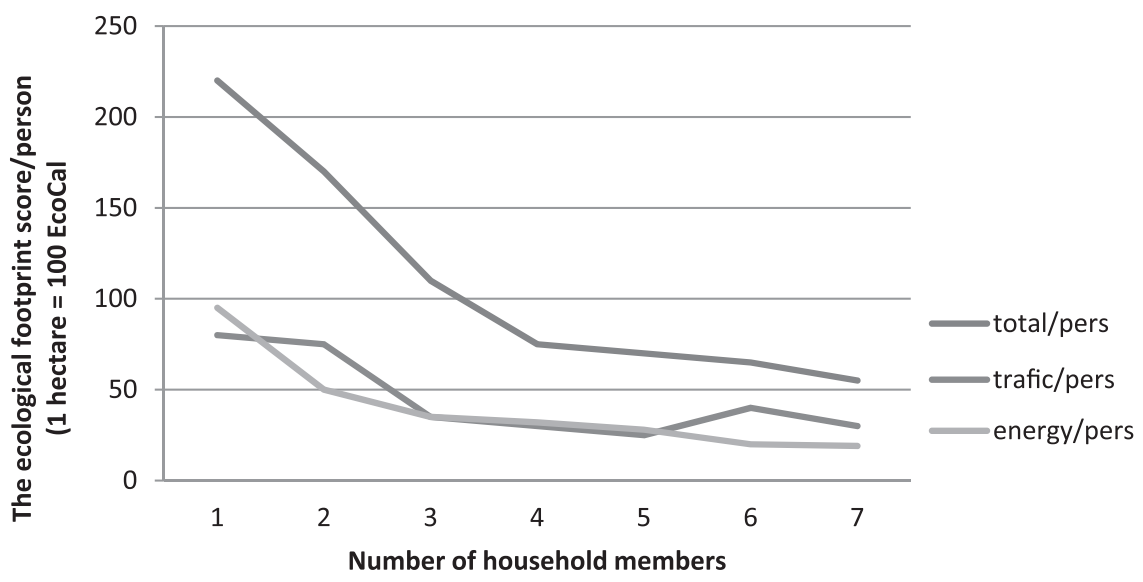

Source: Roy and Caird (2002) 


\section{Methods}

This study is part of wider research within which various methods have been adopted or developed in order to investigate the complexity of lifestyle of a sample of Czech singles ${ }^{4}$ chosen both from the general population and among environmentalists ${ }^{5}$ (Kala 2014). The following article is partially based upon qualitative research concerning the lifestyle of singles and solo-living people. The qualitative research is based upon in-depth interviews coded mostly by an "in-vivo" system (see Glaser, Strauss 1967). The analysis of the data was based on interpretative sociology (see Berger and Luckmann 1967). Hence, epistemologically, this work is based on social constructivism. I have adopted the grounded theory method in order to understand how researched singles interpret specific aspects of their lifestyle (Strauss, Corbin, 1997). The presentation of all results of the qualitative analysis is beyond the scope of this article (see Kala 2014). Within this article I will focus only on the aspect of environmental friendliness. Although researched singles have a different way of life, they usually interpret their lifestyle as being environmentally friendly.

The analysis of testimonies of researched singles did not bring deeper understanding of the environmental aspects of their lifestyle ${ }^{6}$. On that basis it was not possible to answer the research question of whether the lifestyle of singles who live alone is inevitably environmentally more damaging than the lifestyles of couples or families and which aspects of their lifestyle have the greatest environmental impact. Therefore it was decided that the interview was to be supplemented by the questionnaire. The aim of the questionnaire was to find specific information about consumption and the environmental aspects of lifestyle. Data collected by the questionnaire was used to calculate individual ecological and carbon footprints. A calculation of the ecological (or carbon) footprint was chosen as the best instrument for allowing us to compare our researched groups and the general population. It allows us to understand the environmental pressures associated with particular aspects of their lifestyle.

The questionnaire was created in order to quantify the respondents' statements. It was filled out by respondents online. There were four question circles: sociodemographic indicators, questions regarding consumption of food and other stuff, questions regarding energy consumption and finally, questions regarding transport habits. The reference period was

4 The average age of the respondents was 35 years; most of them had a college education ( $88 \%$ ), and the majority of them were employed $(80 \%)$ - mostly in education and the non-profit sector. Their monthly net income mostly ranged from 20001 to $25000 \mathrm{CZK}$ (non-green singles) and 15,00120,000 CZK (green singles). Their average monthly housing costs were 9,392 CZK (non-green singles) and 4,588 CZK (green singles). While more than half of non-green singles lived in their own houses, green singles mostly lived in rented accommodation.

5 The criteria for selecting respondents were as follows: adulthood, non-cohabitation (living without a partner), childlessness, independent household economy. Respondents were selected in two research groups: non-green singles (15) and green singles (21) - those who are perceived as single environmentalists by their social surroundings and those who identified themselves with the designation "green single". The selection of respondents was carried out by the targeted sampling, allowing me to address hidden populations of these researched singles (cf. Watters and Biernacki 1989).

6 Within this article testimonies have rather illustrative purpose. 
the year 2014. Questions were both closed and open, derived from calculators of ecological footprint and from past research (Calla 2014; Zelený kruh 2014; Roy and Caird 2002). Respondents were asked to respond at the base of their own measurement and self-evaluation. The questionnaire was sent six months after the research interviews. 12 non-green singles and 18 green singles ${ }^{7}$ responded.

\section{Results}

Work is a key aspect of the lifestyle of surveyed singles. A strong work ethic can be seen in our respondents, regardless of how and where they work. In the life of the singles surveyed, work represents not only a means of taking care of themselves, but also holds value in the areas of identity, social contact, and sense of purpose. Among the surveyed singles, and especially for those for which their work was also their calling, it was common to work overtime, from home, and on vacation. In such cases, work then very easily becomes a dominant feature of their lives (see Kala 2014).

The hypertrophy of working hours has some environmental consequences. On the one hand, work itself can contribute to environmental destruction (cf. Schütz 1989; Fraňková 2007), and on the other hand, the money it generates poses a risk of overconsumption and entanglement in the vicious circle of overwork and over consumption (Robinson 2006). The fact that singles earn relatively more money is documented by many studies (cf. Klinenberg 2012b; Hawk 2011). The respondents in my research earn more per person than is common in multi-member Czech households (cf. CSO 2013). The net monthly income of the singles surveyed mostly ranged between 15,001-20,000 CZK (green singles) and 20,001 to 25,000 CZK (non-green) per month.

The relatively higher incomes enable singles to live independently. Of the 36 respondents in this research, 23 live alone. In addition, older singles tend to live in single-person households, often privately owned. Even green singles do not expect life in a shared housing to be long term. Besides the economic rationale and environmental friendliness, the need for privacy and control over their housing is also to be found in the respondents' answers. Pravdomila, a green single, illustrates this in her testimony:

That's how it is when you are pushing thirty. And I had a relatively large savings account, and I knew that the money wouldn't increase just sitting in the account. And rents are quite expensive, so I didn't like it from an economic point of view (...) In addition, when I lived in lodgings, there was always a landlady, and some other people with whom we took turns in the bathroom, and in my own apartment all this falls to the wayside, which also played a role...

Although most of the surveyed singles had experience with roommates (95\%), only some could imagine living like that long term. Room sharing was viewed by many respondents as a temporary, immature form of housing, which does not provide sought after future security. For many of the surveyed singles independent living means a definitive detachment

The missing data about energy consumption from the rest of the sample I get additionally by phone. 
from their parents. The existence of one's own household serves as a visible symbol of their maturity. An important motive for buying an apartment is the need to have some control over one's destiny. The acquisition of property (including independent renting) is thus primarily a symbolic act within the social environment. An important incentive, especially for male singles, for the construction or reconstruction of a house is the "reconstruction of the personal biography", fulfilling their wishes about themselves (cf. Galčanová, Vacková 2014). Although singles do not currently need property for a family, they often buy it with the prospect of family housing. Therefore they prefer housing similar to multi-person households, in which, however, they often live alone. ${ }^{8}$ The average habitable floor area of the surveyed singles' homes is $60 \mathrm{~m}^{2}$ (green) and $65 \mathrm{~m}^{2}$ (non-green) per capita. After adjusting for roommates it is $30.7 \mathrm{~m}^{2}$ (green) and $49.1 \mathrm{~m}^{2}$ (non-green), which is more than the national average. ${ }^{10}$

An obstacle to room sharing, which in the case of singles represents a more environmentally friendly form of housing ${ }^{11}$, can according to the analysis of the respondents be "squeamish individualism" 12 . The sharing of objects considered to be intimate is problematic. Rooms associated with hygiene and food preparation, especially the bathroom and the kitchen, pose a problem for room sharing (cf. Williams 2003: 92; Gregson 2007: 43). In the context of singles, squeamish individualism leads to an increase in consumption. An iconic object that singles buy for themselves is the washing machine. A strong desire for the ownership of a washing machine is not even alleviated by the significant socializing potential of public laundries. Respondents maintained that the washing machine is an element which represents a separate independence from the original family, from home (cf. Watson 2014).

Although singles use houses differently than families (e.g. few cook, they don't spend free time at home), they often equip households like them. However, many amenities typical of family households were absent for the surveyed singles. A surprising finding of our research was the absence of a television in most of the surveyed households. But this is not only about television. Figure 2 shows that both of the monitored populations own significantly fewer electronic devices (television, satellite, DVD players, etc.) than a representative sample of the Czech population. While the absence kitchenware probably indicates a different culture of eating and food storage, the absence of home electronics reflects a different way of spending leisure time. Because the surveyed singles spend much of their time outside

8 According to British research, $90 \%$ of singles crave the same housing as families (cf. Williams 2003). The current Czech one-member household has an average of 3 rooms covering an area of $68 \mathrm{~m}^{2}$ (Habartová 2014). An increasing number of single-member households have higher and higher demands on energy, goods, services and infrastructure (cf. Kušková 2009).

9 On average, the inhabitants of the Czech Republic have $32.5 \mathrm{~m}^{2}$ of living space (CSO 2011b).

10 While 10 (out of 21) green singles live in shared apartments, just 3 (out of 15) non-greens have a room-mate.

11 Thanks to room sharing, they save, on average, $31 \%$ of the space, $57 \%$ on electricity and $8 \%$ on the purchase of goods. In particular, the need for the individual ownership of larger appliances (washing machines, freezers) falls, within the community of room sharing, on average by $25 \%$ (Williams 2005: 165).

12 With increasing individualization, the willingness to share is reduced. This phenomenon is called squeamish individualism (Librová 2003: 277). 
the home, eating and enjoying the outdoors, they do not have as great a need to own home electronics compared to conventional households.

Figure 2: The number of certain appliances in the surveyed households ${ }^{13}$

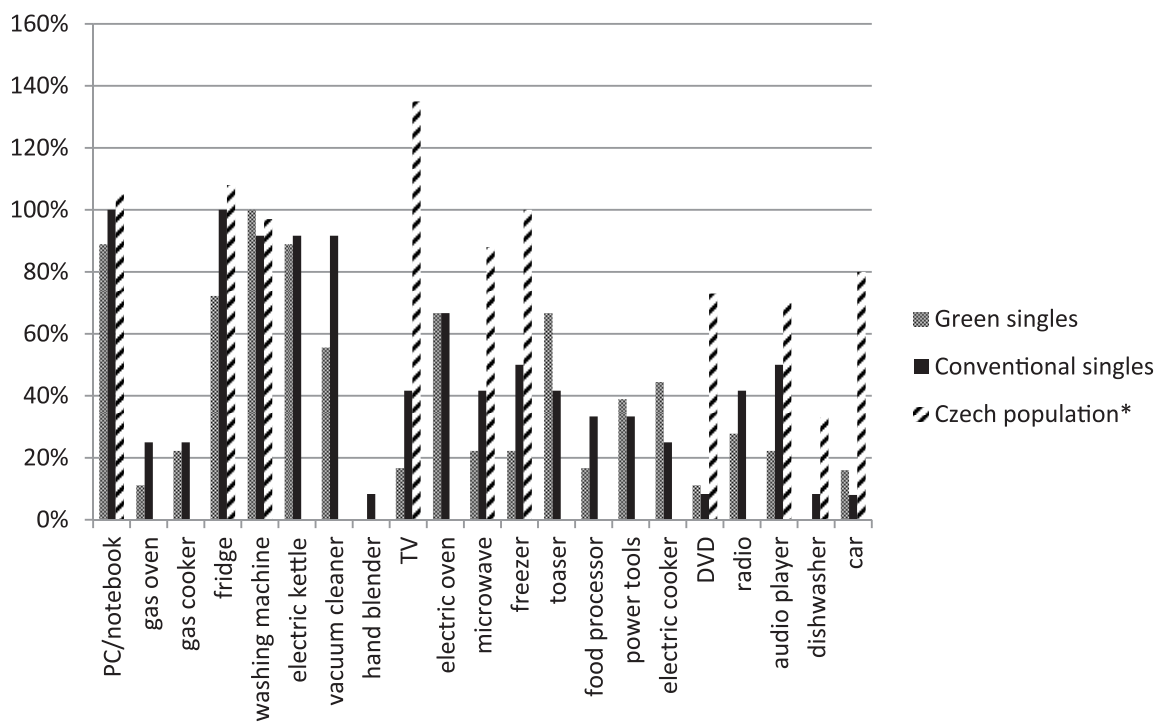

* Source: Household Budget Survey ${ }^{14}$ CSO (2013)

In order to determine the characteristics of the material consumption of the surveyed singles I chose two indicators. The first is the frequency of changing the wardrobe, or buying new clothes ${ }^{15}$. While green singles visit clothing stores once or twice a year, non-greens buy new clothes every quarter. In addition, as far as the consumption of electronics goes, nongreen singles consume more. Mobile phones ${ }^{16}$, which are currently owned by the majority of the population, were also chosen as an indicator. Respondents were asked how much they have used their phone in the last five years and how old their device is. While non-greens

13 The amount of appliances were studied in 21 households of green and in 15 households of non-green singles.

14 For ilustration, I present the results of an investigation of household amenities performed on a quota selection of the population of the Czech Republic. The missing column means that the data is not tracked by the statistics. In the framework of this investigation, the number of household appliances was taken into consideration, and, therefore, some values exceed $100 \%$.

15 I chose textiles as an indicator because its consumption (particularly cotton) carries both a considerable ecological and water footprint (cf. Chapagain 2006).

16 I chose mobile phones as an indicator because their production is very demanding on energy and resources from the environmental perspective (Frey 2008). At the same time, the ownership of a mobile phone is not purely utilitarian and its frequent replacement occurs on account of fashion. 
change mobile phones as often as the average of the Czech population ${ }^{17}$, greens use their mobile phones much longer. The age of mobile phones for non-green respondents is about 22.8 months, compared to the mobiles of green singles which serve their users on an average of 42.6 months.

Given that the examined singles mostly do not own a car, almost none of them shop in supermarkets and shopping malls. Roughly half of both groups buy most of their food in smaller supermarkets. The popularity of small supermarkets is startling, while ethical or environmental reasons are practically unheard. Václav shops in them because it's on the way home from work, Filip again because it is close, Jana and Lilly, because they are open late, Hynek because he is too "lazy to go anywhere else," and Anna, because they know her in the store.

A heavy workload, a lack of cars and only occasional shopping can have an unintended positive effect on reducing the impact of consumption on the environment. Respondents who buy food in small amounts and only occasionally, more often take into account the ethical and political aspects of the products when shopping - e.g. buying local products and supporting local small shops (cf. Jamieson, Simpson 2013: 126). The offer of retail chains is rated as poor quality by the surveyed singles. Not only green singles look for a strategy on how to buy healthy and environmentally friendly foods. A significant proportion of respondents (26 of them) usually buy some products with a high ideological value. Apart from goods from the market they include vegetables directly from farmers, items from food banks, cultivars obtained under LETS or certified products (fair trade, bio etc.).

It is not surprising that green singles buy certified food and products. Interestingly, nongreen singles also buy many certified products. They are not trying to lead an ascetic life, but rather they deliberately decide on what they spend their money on and what they support. In both groups we see a significant shift towards post-materialist values manifesting in smaller and more selective consumption.

Finding similar products (e.g. fair trade coffee) in the households of green and nongreen singles illustrates the similar cultural milieu of both groups (academic circles). The consumption of certified products and goods with great ideological value points out the cultural importance of objects as holders of meaning. The assemblage of these things gives visibility to the hierarchy of values and attitudes of their owner, thereby creating a clear picture of them to others and confirming certain cultural patterns and categories (Douglas 1978: 67).

The singles surveyed have, almost without exception, emotional attachments to the things which surround them. Generally, in the households of singles mainly, memorabilia relating to their relationships with absent loved ones appear. Such objects are only rarely disposed of. Throwing out things which are tied to memories is a problematic activity for the surveyed singles. Memorabilia ${ }^{18}$ are important and difficult to get rid of. The emotional

17 According to a Reuters poll, Czechs change mobile phones every two years (ČTK 2014).

18 In most households, there is a critical distinction between the things of daily consumption and the things that previously could serve for normal daily consumption, but today are regarded as sacred, because they embody certain memories that are bound to them (Gregson 2007: 19). 
attachment to things can dampen consumption, which can be taken as environmentally friendly (see Kala 2014).

Rather surprisingly, both groups are interchangeable in terms of waste sorting. In particular, paper, plastic and glass are sorted by the vast majority of respondents in both groups. There are, however, slight differences between the two groups. Greens are the most thorough in sorting waste. Compared with non-green singles they also sort metals and bio waste more often $^{19}$, even in cases where the city does not ensure their collection. Non-green singles, on the other hand, are more likely to recycle clothing (3.3 times more often), which however may be due to the fact that they buy more of it and do not get rid of it through secondhand stores like greens.

\section{Energy consumption ${ }^{20}$}

A surprising finding was that both groups have lower energy consumption per household and per capita than the national average ${ }^{21}$. In the households surveyed, green singles recorded an annual average consumption of $1665 \mathrm{kWh}(771 \mathrm{kWh}$ per capita) and in non-green singles households even $1264 \mathrm{kWh}$ ( $896 \mathrm{kWh}$ per capita). It is surprising that a similar deviation from the national average is also seen with the consumption of other forms of energy such as gas and district heating. While the national average gas consumption, according to the statistics of the Energy Regulatory Authority, is around 25 thousand kWh per year (per household consuming gas), among the green singles surveyed, the average consumption was estimated at 5,604 kWh and for non-greens at 10,860 kWh.

These low levels of energy consumption reveal a certain thriftiness of green singles on the one hand, and on the other hand they point to their alternative way of life. The average is decreased, for example, by Radka, who lives in a garden shed heated by wood, or Fabián who lives in a small room without heating in an old industrial area. Low power consumption, however, is also achieved by those who bet on environmentally friendly technologies, like Cyril. His insulated house, heated with wood and solar water heating, with the manual drive of most systems and a cellar in the place of a refrigerator. It consumes $888 \mathrm{kWh}$ of electricity per year and $5 \mathrm{~m}^{3}$ of wood (= about 15,200 $\mathrm{kWh}$ of energy).

In particular, green singles have a profound knowledge regarding their consumption. They are able to identify what is behind their energy consumption. They do not overlook "systems in the background", which operate passively, but more continuously - heating, refrigerator etc. They actively try to reduce their consumption of energy. Although they live alone they have lower energy consumption per capita than multi-person households.

19 The majority of green singles sort metals (15) and nearly half of them sort bio-waste (11), while just 4 of the non-green singles sort metals and two of them bio-waste.

20 Data from the respondents own reading of measurement devices or invoices.

21 According to the statistics of the Energy Regulatory Authority, the average annual electricity consumption of the common 2.5 member Czech household is around $3500 \mathrm{kWh}$. 


\section{The ecological and carbon footprint}

Although the lifestyles of both groups appeared to be similar during the field investigation, the calculation of the ecological and carbon footprints showed that they differ in certain respects after all. Interesting is not just the size of the ecological and carbon footprints, but also the proportion of their components. While the consumption of food had the greatest impact on the ecological and carbon footprint for green singles, the categories of goods and services are the most dominant with non-greens . In the case of green singles, however, this does not mean that their ecological and carbon footprint associated with food consumption was particularly high. Rather, it is that their impact in other areas is low.

Figure 3: The average ecological and carbon footprints of researched households

\begin{tabular}{|r|r|r|r|r|}
\hline \multicolumn{5}{|c|}{ Ecological footprint of green singles gha/year } \\
\hline housing & goods and service & food & transport & total \\
\hline 0,4 & 0,7 & 0,8 & 0,2 & 2,1 \\
\hline
\end{tabular}

\begin{tabular}{|r|r|r|r|r|}
\hline \multicolumn{5}{|c|}{ Ecological footprint of coventional singles gha/year } \\
\hline housing & goods and services food & transport & total \\
\hline 1,6 & 2,5 & 1,2 & 0,6 & 5,9 \\
\hline
\end{tabular}
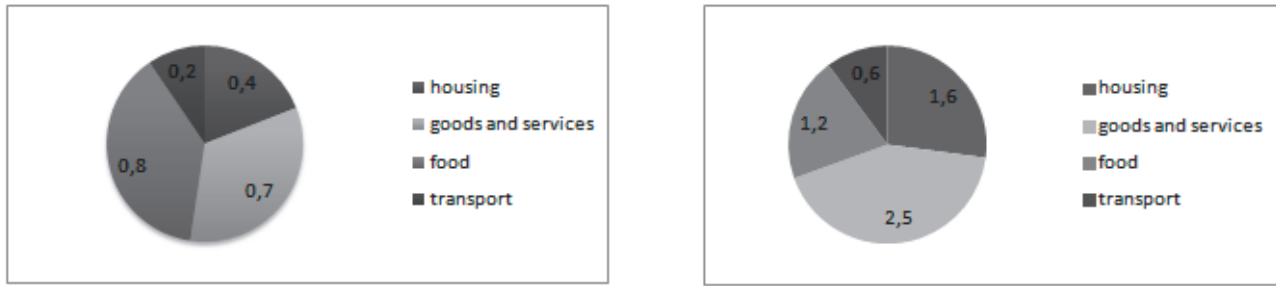

\begin{tabular}{|c|c|c|c|c|}
\hline \multicolumn{5}{|c|}{ Carbon footprint of green singles t ekv.CO2/year } \\
\hline housing & transport & food & waste & total \\
\hline 4,45 & 1,26 & 0,67 & 0,2 & 6,58 \\
\hline
\end{tabular}

\begin{tabular}{|c|c|c|c|c|}
\hline & $f$ & sin & ngles t ek & \\
\hline housing & transport & food & waste & total \\
\hline 8,6 & 4,6 & 0,8 & 0,3 & 14,3 \\
\hline
\end{tabular}
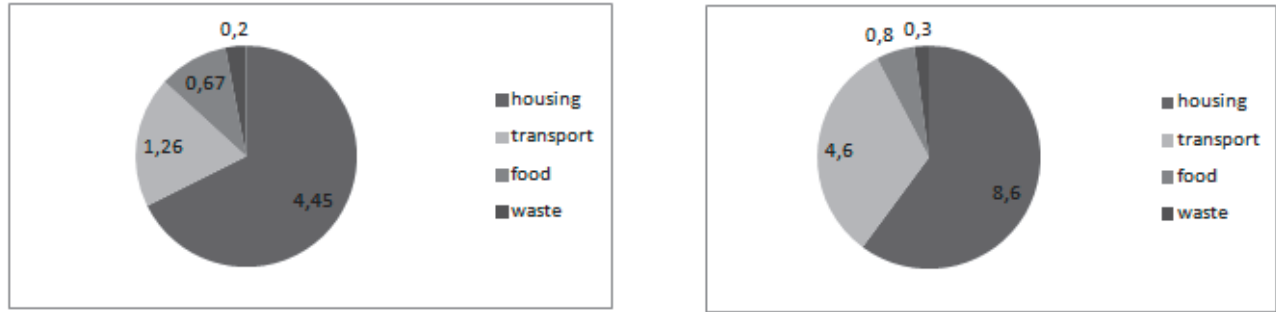

According to the data of EUREAPA (2004), the ecological footprint of a Czech citizen should correspond to 4.77 global hectares (gha) and 13.8 tons of carbon eq. $\mathrm{CO}_{2}$. While non-green singles are slightly above average in both categories and would need 3.3 planets to meet their needs, green singles are significantly below average and 1.2 times the planet would be sufficient for them ${ }^{22}$.

22 I emphasize that it was not a precise determination of the ecological and carbon footprints, which is not even possible, but a capturing of certain aspects of lifestyle and the specifics of non-green and green singles. 
Figure 4: The average ecological and carbon footprints of Czech households

\begin{tabular}{|r|r|r|r|r|}
\hline \multicolumn{5}{|c|}{ Ecological footprint of Czech housholds gha/year/pers. } \\
\hline housing & goods and service & food & transport & total $^{*}$ \\
\hline 1,01 & 2,13 & 1,43 & 0,63 & 4,76 \\
\hline
\end{tabular}

\begin{tabular}{|r|r|r|r|r|}
\hline \multicolumn{5}{|c|}{ Carbon footprint of Czech housholds t ekv.CO2/yearl } \\
\hline housing & goods and services food & transport & total $^{*}$ \\
\hline 3,35 & 2,54 & 1,79 & 2,31 & 12,23 \\
\hline
\end{tabular}
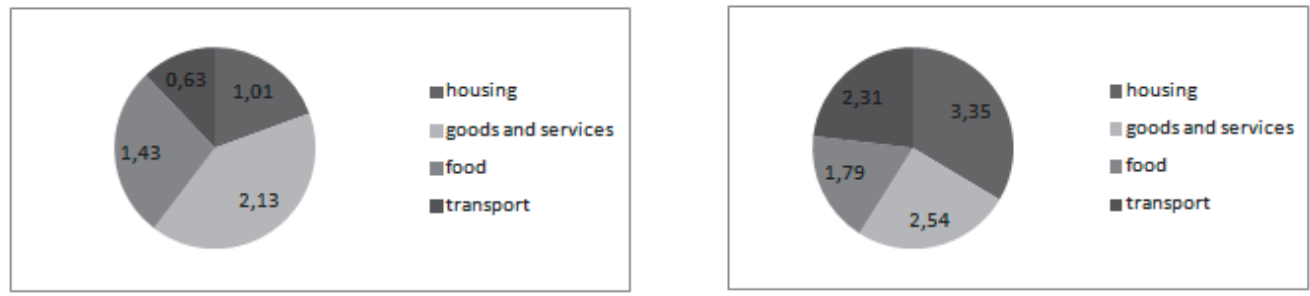

Source: Zelený kruh 2014, EUREAPA 2004

How is it that the green singles surveyed have significantly lower ecological and carbon footprints, even though they mostly live the same as non-greens? The key factor seems to be roommates. The more people that share a particular living space and equipment, the lower each one's ecological footprint is. If we look at housing in terms of the ecological footprint, we realize that every square meter of built-up area is responsible for the occupation of 6.2 to $9.4 \mathrm{~m}^{2}$ of biologically productive land, which in the case of an average household in the group of non-green singles corresponds to an area of some $461 \mathrm{~m}^{2}$ (or 0.04 global hectares) ${ }^{23}$. That in itself is not much, but if we add the energy and materials required for construction, furnishings and energy necessary for its operation, we get up to 2 gha/year for singles living in one-member households. ${ }^{24}$

In addition, transportation is a key element which raises the ecological and carbon footprint of non-green singles. Although the two groups basically do not differ in their modes of everyday transportation, even as far as the amount of mileage ${ }^{25}$, they basically have a double ecological footprint in this category - they also produce four times more greenhouse gases. The difference between the two groups lies in air transport. While the surveyed green singles spend about 4.3 hours a year in aircraft (approximately 3,500 km flown), non-greens spend

23 The calculation is derived from the research of the investigator Bastianoni et. al (2006) who calculated that the construction of a four-storey condominium and a detached house determines the annual bio-productive area requirement of 6,290 and 9,465 $\mathrm{gm}^{2}$ respectively.

24 The most prominent component of the ecological footprint is household electricity consumption and energy for heating, which in the case of the single-member households is higher per capita (EUREAPA 2004).

25 On average, green singles travel $24.5 \mathrm{~km}$ a week by car (including as passengers) and $111 \mathrm{~km}$ by public transport. Non-green singles travel $36.6 \mathrm{~km}$ a week by car (including as passengers) and $113 \mathrm{~km}$ by public transport. 
25.7 hours (about 20,500 km flown) ${ }^{26}$. The more kilometers traveled is then responsible for their larger environmental footprint.

In the case of food, the lower consumption of animal protein is undoubtedly responsible for the lower ecological and carbon footprint of the green singles surveyed. I found a significant difference between the green and non-green groups of singles in eating. Non-green singles more often eat food which contains animal proteins than green singles ${ }^{27}$. While for the group of green singles, almost half ( 8 of them) do not eat meat, and three of them are even vegans, for non-greens I came across only two vegetarians. In addition, the effort of green singles to eat local food and to be self-sufficient also reduces the ecological and carbon footprint.

Although both groups are in many respects interchangeable (e.g. sorting waste, focusing on non-material consumption) and where they differ from the average Czech household, I identified a significant difference in their carbon and ecological footprint. The main distinguishing factors are the independent housing and frequent foreign flights of the non-green singles.

\section{Conclusions}

The purpose of the current study was to investigate the environmental and non-environmental aspects of single people's lifestyles. Returning to the question posed at the beginning of this study, it is now possible to state that the lifestyles of singles cannot be automatically considered to be environmentally unfriendly. This study has shown that environmentally-friendly changes in lifestyle can reduce the overall environmental impact of solo living.

This study has found that generally solo living is more environmentally damaging than flat-sharing. This study supports previous research findings that smaller households are less efficient in terms of energy consumption, transportation and occupation of space per person. The purpose of the current study was to determine particular environmentally unfriendly aspects and consumption patterns of single people's lifestyles. These findings suggest that long-distance travel, overconsumption and a carnivorous diet (especially based on imported goods) represent in general the greatest environmental burden. From an environmental perspective, overwork and individualism are also problematic. However, these lifestyle aspects are not typical just for singles; in their case the environmental harm is most evident.

The results of this investigation show that certain aspects of singles' lifestyles (high workload, city centre living, absence of car) can have environmentally-friendly effects such as reduction in consumption (of both goods and energy). Because the surveyed singles spend much of their time outside the home (eating and having fun outdoors), they do not need a lot

26 This roughly corresponds to the ratio of $0.7 \mathrm{t}$ compared to the 4.4 tonnes of emissions eq. of $\mathrm{CO}_{2}$. Also interesting is the ratio of those who fly a lot and those who still hadn't flown in 2014. While 14 of the green singles did not fly at all, 10 of the non-green singles flew more than 10 thousand miles.

27 Non-green singles marked in the questionnaire that they eat animal proteins occasionally (2), quite often (7) and daily (3), while green-singles eat them occasionally (6), quite often (7), daily (2) and never (3). 
of electronic appliances in comparison to conventional households. However, they sometimes equip their households similarly to families and occupy excessively large housing.

One of the most significant findings to emerge from this study is that there exist measurable differences between the environmental impact of the lifestyles of green and conventional singles. While the researched group of conventional singles has an ecological and carbon footprint slightly higher than the national average (6.5 gha and $14.3 \mathrm{t} \mathrm{CO}_{2}$ per year), green singles have both footprints significantly lower (2.1 gha and $5.9 \mathrm{t} \mathrm{CO}_{2}$ per year). The researched green singles use 1.2 times of the bio productive land as we have on the Earth, whereas the researched conventional singles will use 3.3 times more of our planet. My research has shown that the deliberate attempts of green singles to reduce their impact on the environment (declared in their testimonies) are relatively significant. Although the current study is based on a small sample of participants, the findings suggest that pro-environmental behaviour matters. Conclusively, singlehood and solo living cannot be automatically considered as environmentally unfriendly. My research may contribute to a more diversified view of the environmental impact of lifestyle of singles and it may be beneficial to consider the expected growth in singles, with which our society will have to deal. More research is needed, however, to determine the environmental impact of consumption patterns amongst singles and one-person households. The growing number of people living alone still potentially represents an environmental risk.

\section{References}

BASTIANONI, Simone et al. 2006. "The ecological footprint of building construction." Pp. 345-356 in The Sustainable City IV: Urban Regeneration and Sustainability, edited by Ülo MANDER, Carlos A. BREBBIA and Enzo TIEZZI. Southampton: WIT Press.

BERGER, Peter L. and Thomas LUCKMANN. 1967. The social construction of reality: a treatise in the sociology of knowledge. London: Penguin Press.

BRADBURY, Mason et al. 2014. "Long-term dynamics of household size and their environmental implications." Population and Environment 36(1): 73-84.

CALLA. 2014. "Kalkulačka uhlíkové stopy.” Retrieved July 15, 2015 (http://kalkulacka.zmenaklimatu. $\mathrm{cz} /$ ).

CHAPAGAIN, Ashok Kumar et al. 2006. "The water footprint of cotton consumption: An assessment of the impact of worldwide consumption of cotton products on the water resources in the cotton producing countries." Ecological economics 60(1): 186-203.

CINCOTTA, Richard. P. and Robert ENGELMAN. 2000. Natures place: human population and the future of biological diversity. Washington D. C.: Population Action International.

ČESKÝ STATISTICKÝ ÚŘAD. 2011a. Datové publikace ze sčitání 2011. Praha: Český statistický úřad. Retrieved July 15, 2015 (http://vdb.czso.cz/sldbvo/).

ČESKÝ STATISTICKÝ ÚŘAD. 2011b. Prưměrná obytná plocha obydlených bytů v prepočtu na 1 byt a 1 osobu podle druhu domu a podle velikostních skupin obci a krajů. Praha: Český statistický úřad. Retrieved July 15, 2015 (http://1url.cz/GDwj).

ČESKÝ STATISTICKÝ ÚŘAD. 2013. Př́imy a životní podmínky domácností v roce 2013. Praha: Český statistický úřad, 2013. Retrieved July 15, 2015 (http://bit.ly/1Be1Q3b). 
ČESKÁ TISKOVÁ KANCELÁŘ. 2014. "Mobily Češi mění již každé dva roky, notebooky po třech letech.” Deník.cz, August 2. Retrieved July 15, 2015 (http://bit.ly/1FfyccO).

DOUGLAS, Mary and Baron ISHERWOOD. 1978. The world of goods: Towards an anthropology of goods. London: Allen Lane.

EUREAPA. 2004. “One Planet Economy Network.” Retrieved July 15, 2015 (https://www.eureapa.net).

FAWCETT, Tina et al. 2002. Carbon in the UK Economy. Oxford: Oxford University Press.

FRAŇKOVÁ, Eva. 2007. Niči práce svět? Použitelnost 2. termodynamického zákona a pojmu entropie $v$ environmentální argumentaci. Diploma thesis. Fakulta sociálních studií, Masarykova univerzita, Brno.

FREY, Sibylle D., David HARRISON and Eric. H. BILLETT. 2006. "Ecological footprint analysis applied to mobile phones." Journal of Industrial Ecology 10(1-2): 199-216.

GLASER, Barney and Anselm STRAUSS. 1967. The discovery grounded theory: strategies for qualitative inquiry. Chicago: Aldin.

GRAM-HANSSEN, Kirsten et al. 2009. "One-person households-a growing challenge for sustainability and housing policy.” ENHR-European Housing Research Network Conference'09. Prague: ENHR.

GREGSON, Nicky. 2007. Living with things: ridding, accommodation, dwelling. Wantage: Sean Kingston Publishing.

MARSHALL, Gordon. 1998. “life-style.” Dictionary of Sociology. Retrieved July 15, 2015 (http://www. encyclopedia.com/doc/1088-lifestyle.html).

HABÁRTOVÁ, Pavlína. 2014. Domácnosti jednotlivcư. Praha: Český statistický úřad. Retrieved July 15, 2015 (http://bit.ly/1K784Gn).

HAWK, William. 2011. "Household spending by single persons and married couples in their twenties: a comparison.” The BLS Consumer Expenditure Survey Anthology, 2011: 40-46. Retrieved July 15, 2015 (http://www.bls.gov/cex/anthology11/csxanth6.pdf).

HODGSON, An. 2007. "One person households: Opportunities for consumer goods companies." Euromonitor International. Retrieved July 15, 2015 (http://bit.ly/1zMhpLp).

HOLMANS, Arthur. 1997. "Single Owner Occupiers Who Live Alone." in Housing In England 1995, edited by H. GREEN. London: HMSO.

HOOPER, Alan, Kathleen DUNMORE and Margaret HUGHES. 1998. Home Alone: Volumes 1 and 2. Amersham: The Housing Research Foundation \& National House Building Council.

JAMIESON, Lynn and Roona SIMPSON. 2013. Living alone: Globalization, identity and belonging. London: Palgrave Macmillan.

KALA, Lukáš. 2014. Environmentální aspekty životního způsobu českých singles. Dissertation thesis. Fakulta sociálních studií, Masarykova univerzita, Brno.

KLINENBERG, Eric. 2012. Going solo: The extraordinary rise and surprising appeal of living alone. London: Penguin Press.

KLINENBERG, Eric. 2012b. "Solo nation: American consumers stay single." Fortune. Retrieved July 15, 2015 (http://for.tn/1tBgKKA).

KUŠKOVÁ, Petra, Alena MARKOVÁ and Klára NAJMANOVÁ. 2009. Češi ve spotřebitelském ráji (!?): Vývoj spotreby českých domácností v poslednich dvaceti letech. Praha: CENIA ve spolupráci s Ministerstvem životního prostředí.

LIU, Jianguo et al. 2003. "Effects of household dynamics on resource consumption and biodiversity." Nature 421(6922): 530-533.

NOORMAN, Karl J. and Schoot T. UITERKAMP. 1997. Green Households? Domestic Consumers, Environment and Sustainability. London: Earthscan Publications.

ROBINSON, Timothy. 2006. Work, Leisure and the Environment. The Vicous Circle of Overwork and Over Consumption. Cheltenham: Edward Elgar Publishing. 
ROPKE, Inge. 2001. "The environmental impact of changing consumption patterns: a survey." International Journal of Environment and Pollution 15(2): 127-145.

ROY, Robin and Sally CAIRD. 2001. "Household ecological footprints-moving towards sustainability?" Town and Country Planning 70(10): 277-279.

SANNE, Christer. 2002. "Willing consumers - or locked-in? Policies for a sustainable consumption." Ecological economics 42(1): 273-287.

STRAUSS, Anselm and Juliet M. CORBIN. 1997. Grounded theory in practice. London: SAGE.

ŠKRABAL, Josef and Štěpánka MORÁVKOVÁ. 2003. Sčitání lidu, domů a bytů k 1. 3. 2001 - obyvatelstvo, byty, domy a domácnosti Česká republika. Praha: Český statistický úřad. Retrieved July 15, 2015 (http://bit.ly/1K6ylRn).

VAN DE KAA, Dirk J. 1987. “Europe's second demographic transition.” Population bulletin 42: 1-59.

WATSON, Sophie. 2015. "Mundane objects in the city: Laundry practices and the making and remaking of public/private sociality and space in London and New York." Urban Studies 52(5): 876-890.

WATTERS, John K. and Patrick BIERNACKI. 1989. "Targeted sampling: options for the study of hidden populations." Social problems 36(4): 416-430.

WILLIAMS, Joanna. 2003. Homes for the future: a means for managing the singletons ' consumption crisis?. London: University of London.

WILLIAMS, Joanna. 2005. “One-person households: a resource time bomb?” Transactions on Ecology and the Environment 81: 409-417.

WILLIAMS, Joanna. 2007. "Innovative solutions for averting a potential resource crisis - the case of one-person households in England and Wales." Environment, Development and Sustainability 9(3): $325-354$.

WULFF, Maryann. 2001. "Growth and change in one person households: implications for the housing market." Urban Policy and Research 19(4): 467-489.

ZELENÝ KRUH. Hra o Zemi: kalkulátor ekologické stopy. Online application. Praha: Zelený kruh. Retrieved July 15, 2015 (http://www.hraozemi.cz/files/ekostopa/ekostopa.php).

\section{Author}

Lukáš Kala is assistant professor in Environmental Humanities at Masaryk University, Brno. His research focuses on the investigation of the environmental aspects of lifestyle, particularly of the lifestyle of singles or voluntary simplifiers. He also focuses on research on the environmental aspects of the process of individualization, especially on research on the individualization of environmental responsibility.

Contact: lukas.kala@gmail.com 